\title{
$\mathrm{Ca}$ 첨가에 따른 $\mathrm{Mg}-4 \mathrm{Al}-2 \mathrm{Sn}-\mathrm{xCa}$ 다이캐스팅 합금의 기계적특성 연구
}

\author{
김영민 - 이영철 ${ }^{\dagger}$ - 박용호* \\ 한국생산기술연구원 동남권 지역본부, *부산대학교 신소재공학부
}

\section{Effect of Ca additions on Mechanical Properties of Mg-4Al-2Sn-xCa Die-Casting Alloys}

\author{
Young-Min Kim, Young-Cheol Lee", and Yong-Ho Park* \\ Dongnam Technology Application Division, Korea Institute of Industrial Technology, Busan 618-230, Korea \\ *Department of Materials Science and Engineering, Pusan National University, Pusan 609-735, Korea
}

\begin{abstract}
Representative magnesium alloys applied to the die-casting are AZ91, AM60, etc., and the application of these alloys is restricted to components operating at moderate temperatures, due to grain boundary siding of $\beta$-phase $\left(\mathrm{Mg}_{17} \mathrm{Al}_{12}\right)$ at temperatures above $120^{\circ} \mathrm{C}$. Heat-resistant magnesium alloys such as AE42, AE44 have been developed, but that have been too burdensome to produce because of the expensive rare earth materials. Research work for the development of low-priced heat-resistant magnesium alloy is actively in progress and positive results are being reported. This study aims to investigate the effect of Ca additions on mechanical properties of Mg-4Al-2Sn heat resistant magnesium alloys. Mg-4Al-2Sn alloys with Ca $(0 \mathrm{wt} . \%, 0.3 \mathrm{wt} . \%, 0.7 \mathrm{wt} . \%$, $1 \mathrm{wt} . \%)$ have been produced through the die-casting process for the development of low-priced heat-resistant magnesium alloy, and high temperature tensile tests are performed using the specimens. The results showed that mechanical properties of Mg- $4 \mathrm{Al}-2 \mathrm{Sn}-$ $\mathrm{xCa}$ increased with the addition of $\mathrm{Ca}$ up to $0.7 \mathrm{wt} \% \mathrm{Ca}$ and further addition of $\mathrm{Ca}$ deteriorated the mechanical properties of the alloys. A significant amount of porosity was observed at the sample with $1 \mathrm{wt} \%$. Ca and the longer freezing range of the alloy was believed to cause the formation of porosity.
\end{abstract}

Key words : Mg alloy, Mg-4Al-2Sn, Heat-resistant magnesium alloys, Porosity. Tensile property.

(Received September 6, 2011 ; Accepted October 12, 2011)

\section{1. 서 론}

마그네슘은 현재 상용화된 실용 금속중 가장 낮은 밀도 $(1.74 \mathrm{~g} /$ $\left.\mathrm{cm}^{3}\right)$ 를 가지고 있으며, 이는 경쟁 재료인 알루미늄 $\left(2.69 \mathrm{~g} / \mathrm{cm}^{3}\right)$ 과 비교하여 약 $2 / 3$, 아연 $\left(7.13 \mathrm{~g} / \mathrm{cm}^{3}\right)$ 의 $2 / 5$ 철 $\left(7.87 \mathrm{~g} / \mathrm{cm}^{3}\right)$ 의 $1 / 4$ 수준의 가벼운 경량금속이다. 또한 우수한 비강도, 진동감쇄능, 전자차페성, 절삭가공성등의 특성이 있어 경량화를 통한 연비개선 이 시급한 자동차 및 항공기 산업등에 알루미늄 합금을 대신 할 수 있는 금속으로 그 사용량이 나날이 증대되고 있으며, 현재 자 동차 seat frame, instrumental panel substrate, steering column component, manual transmission housing 등의 수송기계부품에 널리 사용되고 있다[1-4].

일반적으로 AZ91 및 AM60은 상온에서의 기계적강도 및 주 조성이 좋아 대표적인 주조용 마그네슘합금으로 쓰이고 있으나, 이들 합금은 $120^{\circ} \mathrm{C}$ 부근에서 기계적특성이 급격하게 저하되는 단점이 있어 사용온도가 $150^{\circ} \mathrm{C}$ 이상인 자동차 파워트레인 부품 에는 적용하기에 어려움이 있다[5].

최초의 내열마그네슘합금은 1970년대 volkswagen사에서 개발
된 AS41 합금이며, 자동차 crank case에 적용되었다. 이후 내 열마그네슘합금 개발은 크게 두가지로 나뉘어 $\mathrm{Mg}$-Al계열의 다 이캐스팅 비열처리용 합금과 $\mathrm{Al}$ 이 첨가되지 않은 사형주조 및 열처리용 합금으로 개발이 진행 되었다. 다이캐스팅용 내열마그 네슘합금은 $\mathrm{Mg}$-Al계 합금을 대부분 기본 조성으로 하고 rare earth 원소 및 $\mathrm{Sr}, \mathrm{Ca}$ 계 원소를 첨가하여, 열적으로 안정된 2차 상을 형성함으로써 $150^{\circ} \mathrm{C}$ 에서도 사용이 가능한 합금의 개발이 주 로 연구되고 있다[6,7]. $\mathrm{AE} 42, \mathrm{AE} 44$ 합금(Mg-Al-RE)과 $\mathrm{AS} 21$, $\mathrm{AS} 41$ 합금(Mg-Al-Si), ZAC 합금(Mg-Zn-Al-Ca)이 대표적인 다 이캐스팅 내열마그네슘합금이며, ACE522 합금(Mg-Al-Ca-RE), $\mathrm{AJ}$ 합금(Mg-Al-Sr), MRI 합금(Mg-Al-RE-Ca-Mn)은 최근 연구 개발 되어 상용화 단계에 있다. 이러한 노력으로 구동온도가 $150^{\circ} \mathrm{C} 200^{\circ} \mathrm{C}$ 인 자동변속기나 엔진블럭등에 마그네슘합금의 적 용이 가능해졌으나, 대부분의 합금 첨가원소는 고가의 rare earth 원소를 사용하기 때문에 비용적인 부담이 있다[8,9]. 최근 저가형 내열마그네슘합금 부품개발을 위하여 $\mathrm{Sn}$ 을 첨가하여 고 온 안정상인 $\mathrm{Mg}_{2} \mathrm{Sn}$ 을 생성시켜 $150^{\circ} \mathrm{C}$ 이상의 온도에서도 충 분한 열적 안정성을 가진 내열마그네슘합금 개발이 연구되고 있

†E-mail : yclee87@kitech.re.kr 
으나 아직 상용화 단계에는 이르지 못하고 있다[10,11]. 따라서 본 연구에서는 주조성이 뛰어난 $\mathrm{Mg}-\mathrm{Al}$ 합금을 기본 으로 고가의 rare earth 원소에 비해 상대적으로 저가인 $\mathrm{Sn}$ 을 적용한 $\mathrm{Mg}-\mathrm{Al}-\mathrm{Sn}-\mathrm{Ca}$ 계 내열마그네슘합금을 제작하였으며, $\mathrm{Ca}$ 의 첨가량을 달리하여 이에 따른 마그네슘합금의 미세조직 및 기계 적특성 변화를 관찰하였다. ATX420 합금에 $\mathrm{Ca}$ 를 각각 $0,0.3$, $0.7,1 \mathrm{wt} . \%$ 첨가하였으며, 320ton급 다이캐스팅장비를 사용하여 시편을 제조하였다. 제조된 마그네슘합금의 미세조직 변화를 관 찰하였으며, 비중측정을 통해 $\mathrm{Ca}$ 첨가에 따른 다이캐스팅 시험 편의 미세기포 생성에 관한 상관관계를 관찰 하였다. 또한 상온 및 $150^{\circ} \mathrm{C}, 200^{\circ} \mathrm{C}$ 에서 인장시험을 실시하여 상온 및 고온에서의 기계적특성 변화를 검토 하였다.

\section{2. 실험 방법}

\section{1 마그네슘합금 다이캐스팅 시편제조 및 정량분석}

$\mathrm{Mg}-\mathrm{Al}-\mathrm{Sn}-\mathrm{Ca}$ 계 마그네슘합금 다이캐스팅 시편제작을 위하여 pure magnesium(99.8\%), pure aluminum(99.8\%), pure tin (99.8\%), $\mathrm{Mg}-\mathrm{Ca}(40 \mathrm{wt} \%)$ 모합금, Ca granular(99.5\%)을 $150^{\circ} \mathrm{C}$ 로 예비 가열하여 수분을 제거한 후 mild steel crucible 속에 장입하여 전기로에서 용해하였다. $400^{\circ} \mathrm{C}$ 이상의 온도에서 급격 히 산화하는 마그네슘의 특성상 $\mathrm{CO}_{2}+\mathrm{SF}_{6}$ 혼합가스를 주입하여 용해로 내에서 용탕을 보호하였으며, 용해온도는 $680^{\circ} \mathrm{C}$ 에서 실 시하였다. 본 연구에서 제조한 마그네슘합금의 조성은 $\mathrm{Mg}$ $94 \mathrm{wt} . \%, \mathrm{Al} 4 \mathrm{wt.} \%, \mathrm{Sn} 2 \mathrm{wt} . \%$ 를 기본으로 하고 $\mathrm{Ca}$ 를 각각 $0.3 \mathrm{wt} . \%, 0.7 \mathrm{wt} . \%, 1 \mathrm{wt} . \%$ 첨가하는 조건으로 합금설계를 하였 으며, 320ton급 cold chamber die casting 장비를 이용하여 시편 을 제작 하였다.

제작된 마그네슘합금의 정량분석은 $\mathrm{ICP}$ 를 이용한 습식분석 및 spectrometer를 이용한 건식분석을 사용하여 실험하였으며, 정량분석결과를 Table 1에 나타내었다.

\section{2 미세조직관찰}

실험한 인장시험편은 나이탈 용액 및 피크르산을 이용하여 에 칭 하였으며, 광학현미경과 전자현미경(SEM-EDS)을 이용하여 미세조직분석 및 정성분석을 실시하였다. X-ray diffractometry (XRD)를 이용하여 상분석을 하였으며, 결정립크기를 측정하기 위하여 $420^{\circ} \mathrm{C}$ 에서 4 시간 동안 용체화 처리후 피크르산을 이용 하여 에칭을 실시하였다.

Table 1. Chemical compositions of HPDC ATX420 alloys with and without $\mathrm{Ca}$ additions.

\begin{tabular}{ccccc}
\hline Alloy & $\mathrm{Al}$ & $\mathrm{Sn}$ & $\mathrm{Ca}$ & $\mathrm{Mg}$ \\
\hline $\begin{array}{c}\text { ATX420 } \\
\text { ATX420 }\end{array}$ & 4.05 & 2.04 & - & $\mathrm{Bal}$ \\
$\left(\begin{array}{c}\mathrm{Ca}=0.3 w t . \%) \\
\begin{array}{c}\text { ATX420 } \\
(\mathrm{Ca}=0.7 w t . \%)\end{array}\end{array}\right.$ & 4.0 & 2.4 & 0.36 & $\mathrm{Bal}$ \\
ATX421 & 3.82 & 1.8 & 0.77 & $\mathrm{Bal}$ \\
\hline
\end{tabular}

\section{3 미세기포 분석}

시험편의 미세기포 측정을 위하여 ASTM D792의 절차에 따 라 비중을 측정 하였으며, 재료의 비중값과 측정된 비중값의 차 이를 백분율로 나타내었다. 신뢰성 확보를 위해 $1 / 10^{6} \mathrm{~g}$ 까지 측 정이 가능한 미세정밀저울을 이용하였다. 또한 DSC (differential scanning calorimetry)를 이용하여 제조된 시편의 용융점 및 응 고점을 측정하여 응고구간을 계산하였다.

\section{4 기계적특성관찰}

제조된 마그네슘합금의 기계적특성에 미치는 $\mathrm{Ca}$ 의 영향을 관 찰하기 위하여 상온 및 고온 인장실험을 실시하였다. 인장시편 은 봉상으로 ASTM B557규격을 사용하였다. 인장시험 평가는 공기순환방식의 온도 제어가 가능한 $50 \mathrm{~mm} \times 250 \mathrm{~mm} \times 250$ $\mathrm{mm}$ 크기의 box chamber로가 장착된 lever 타입의 마그네슘합 금 전용 인장시험기를 사용하였다. 인장시험은 $25^{\circ} \mathrm{C}, 150^{\circ} \mathrm{C}$, $200^{\circ} \mathrm{C}$ 에서 5 분간 유지시킨 후 분당 $2 \mathrm{~mm}$ 로 인장시험 하였다.

\section{3. 실험 결과 및 고찰}

\section{$3.1 \mathrm{XRD}$ 분석}

$\mathrm{Ca}$ 함량에 따른 시편의 $\mathrm{XRD}$ 분석결과를 Fig. 1에 나타내었다. 분석결과 기본적으로 모든 합금에서 $\alpha-\mathrm{Mg}, \beta-\mathrm{Mg}_{17} \mathrm{Al}_{12}, \mathrm{Mg}_{2} \mathrm{Sn}$ 상의 피크가 검출되었다. 또한 $\mathrm{ATX} 420$ 합금에 $\mathrm{Ca}$ 를 첨가하였 을 시 $\mathrm{CaMgSn}$ 상의 피크가 발견 되었으며, $\mathrm{Ca}$ 의 함량이 높아 질수록 피크의 강도가 높아지는 것이 관찰되었다.

\section{2 미세조직관찰}

Fig. 2(a) (d)는 다이캐스팅을 통해 제조된 Mg-Al-Sn-Ca 합 금의 미세조직 사진이다. 전체적인 조직사진은 밝은영역의 $\alpha$ $\mathrm{Mg}$ 수지상(Dendrite)의 응고셀(Solidification cell) 사이에 이차 상들이 미세하게 생성되어 있는 형태이다. 조직사진에서 볼 수 있듯이 $\mathrm{Ca}$ 의 첨가량이 많아질수록 $\alpha-\mathrm{Mg}$ 상이 미세해지는 효과 가 나타났으며, 입계에 이차상의 생성도 증가하는 것을 확인할 수 있다. $\mathrm{Ca}$ 가 $0.3 \sim 0.7 \mathrm{wt} . \%$ 첨가 시에는 $\mathrm{CaMgSn}$ 상들이 수지

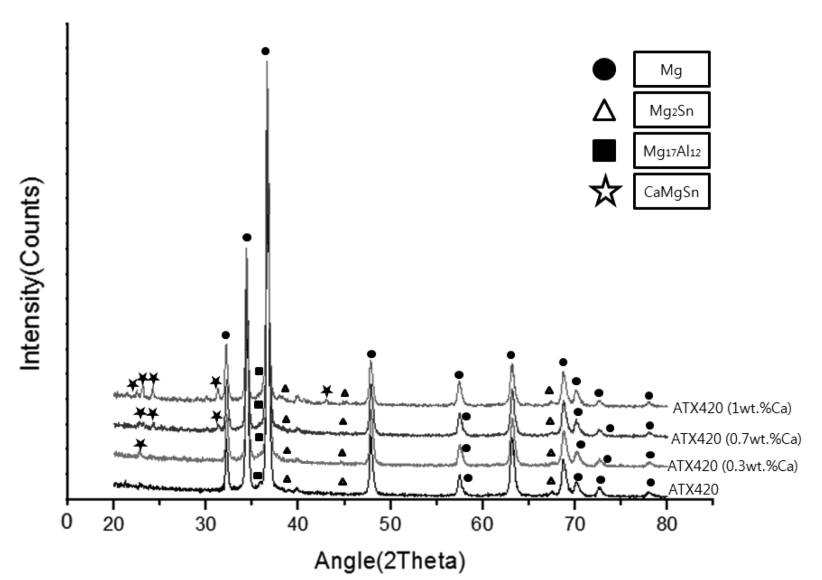

Fig. 1. X-ray diffraction patterns of ATX420 alloys with $\mathrm{Ca}$ additions. 


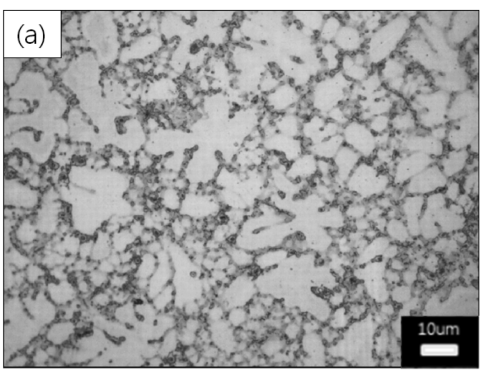

ATX420

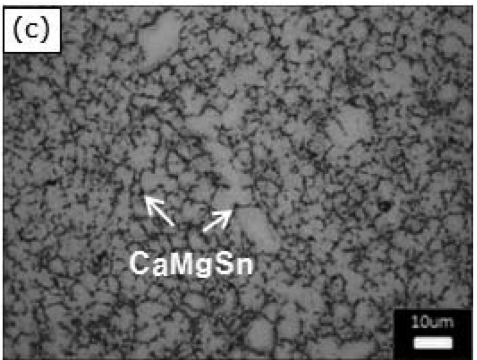

ATX420 $(\mathrm{Ca}=0.7 \mathrm{wt} \%)$

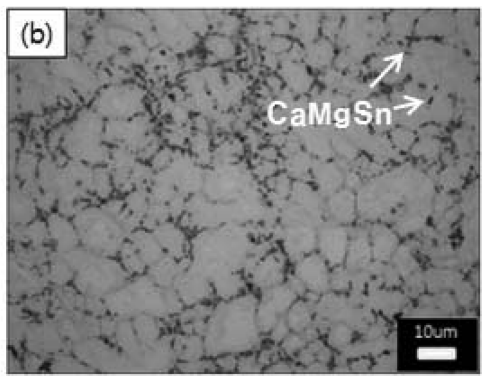

$\operatorname{ATX} 420(\mathrm{Ca}=0.3 \mathrm{wt} \%)$

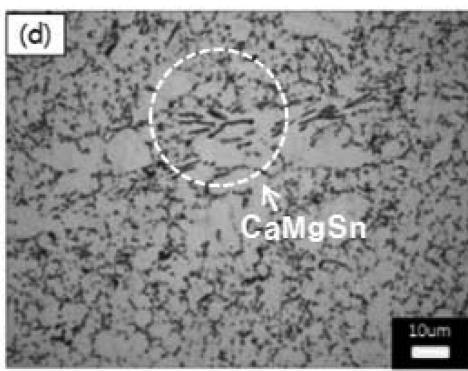

ATX421

Fig. 2. Microstructure of ATX420 alloys with different content of Ca additions.: (a) 0wt.\% (b) 0.3wt.\% (c) 0.7wt.\% (d) 1wt.\%.

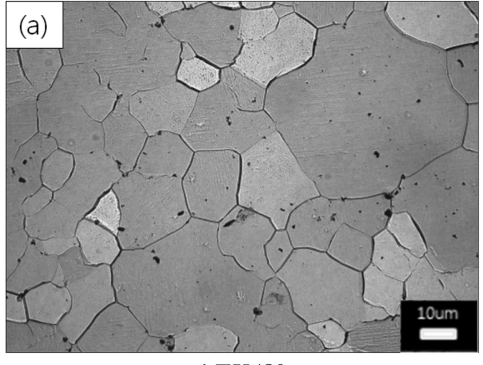

ATX420

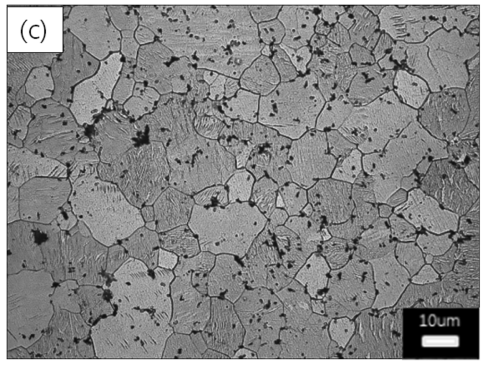

ATX420 $(\mathrm{Ca}=0.7 \mathrm{wt} \%)$

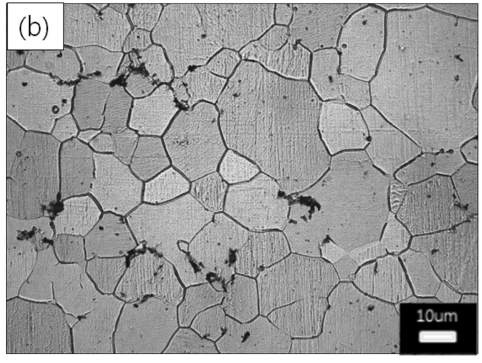

$\operatorname{ATX} 420(\mathrm{Ca}=0.3 \mathrm{wt} \%)$

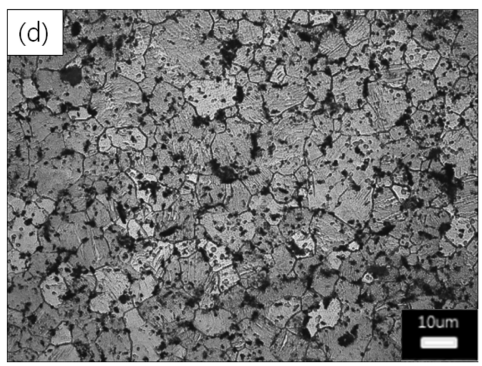

ATX421

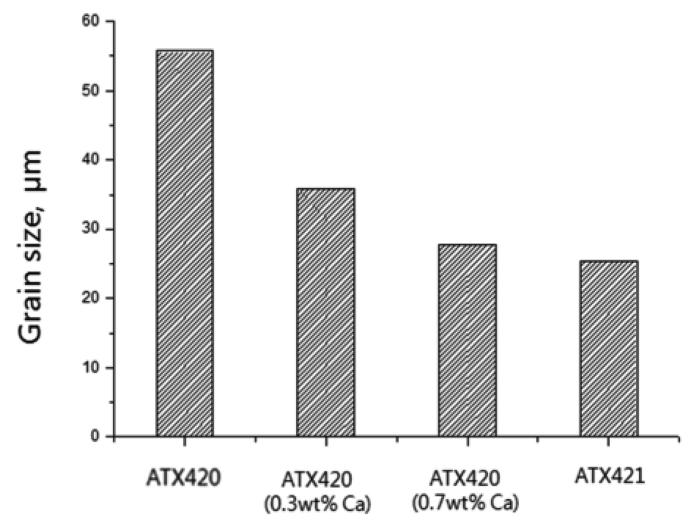

Fig. 3. Micrographs and grain size measurements of ATX420 alloys with different content of Ca additions.: (a) 0 wt.\% (b) $0.3 w t . \%$ (c) $0.7 w t . \%$ (d) $1 \mathrm{wt} . \%$. 

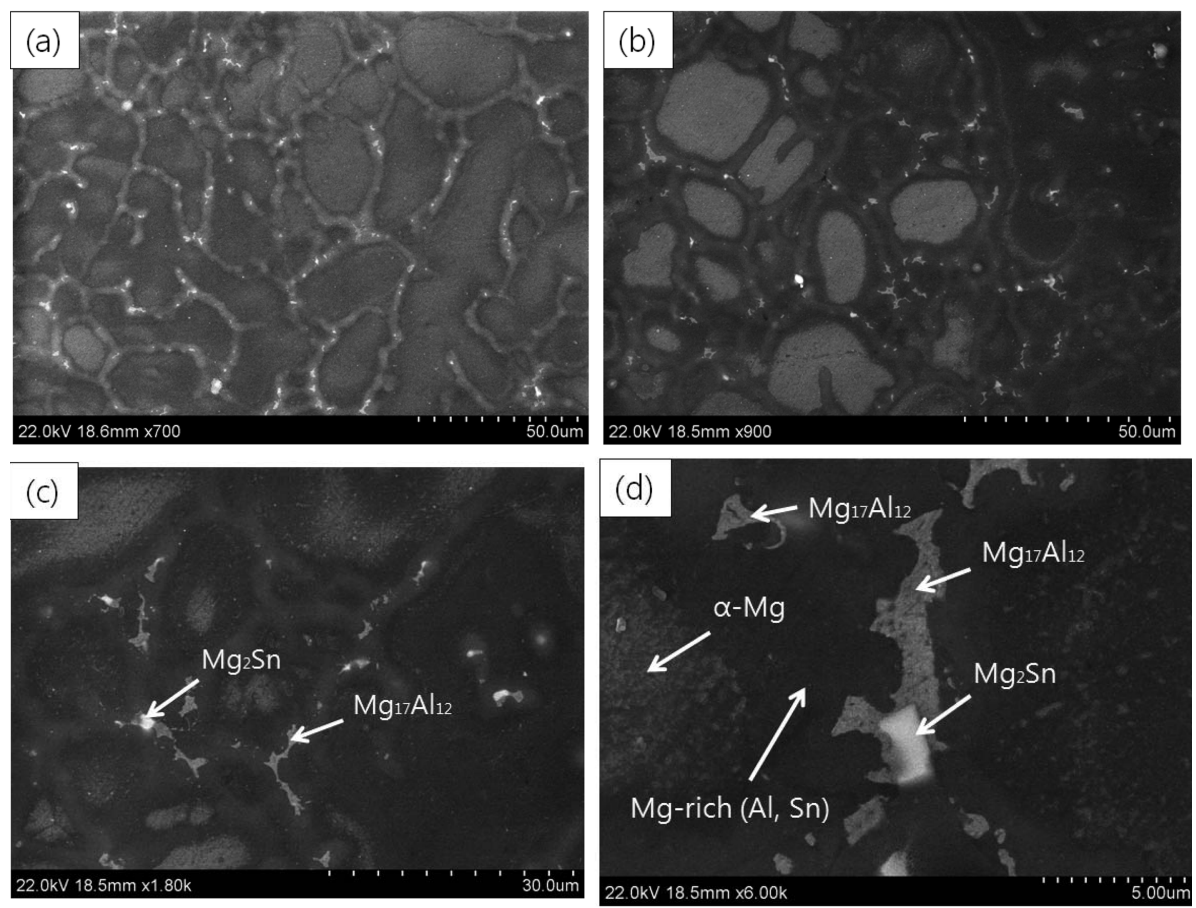

Fig. 4. SEM image of ATX420 alloy.
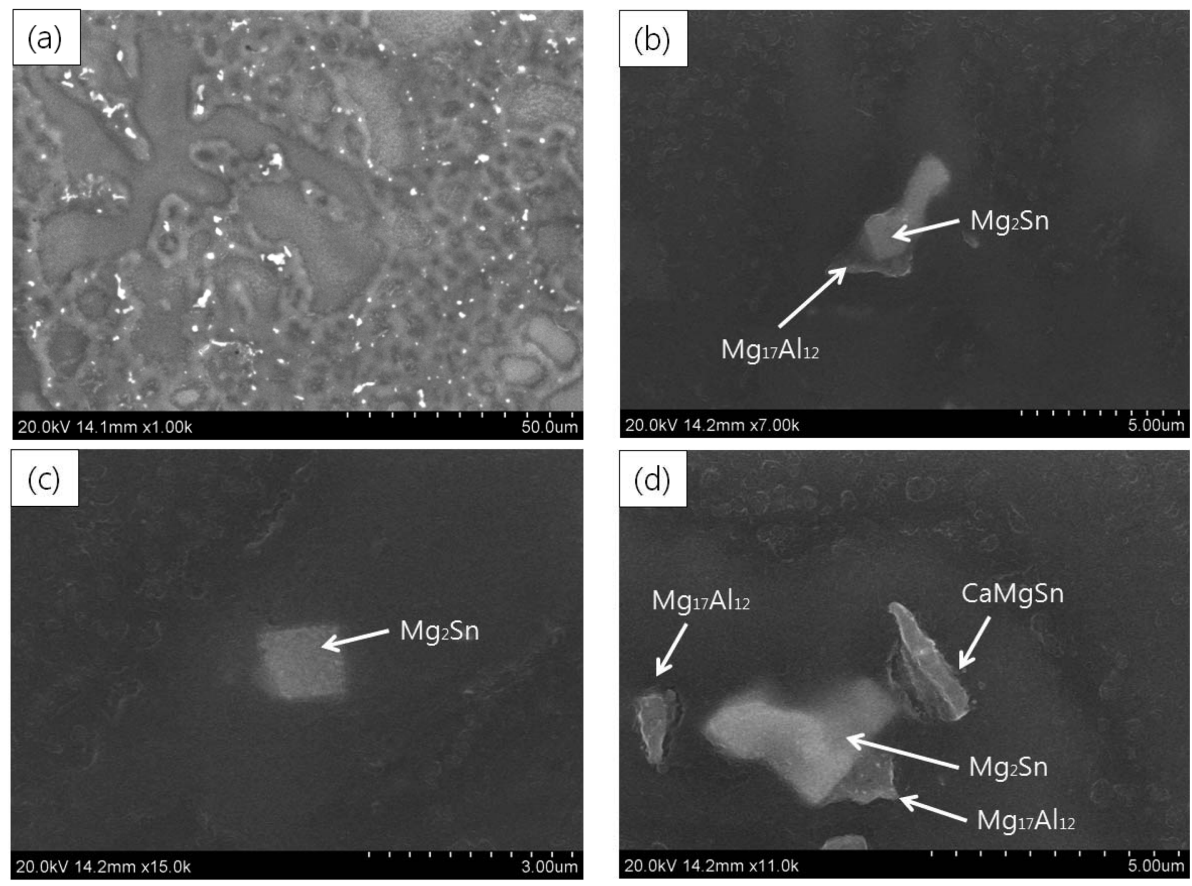

Fig. 5. SEM image of ATX420 $(\mathrm{Ca}=0.3 \mathrm{wt} . \%)$ alloy.

상정 주위에 미세하게 분포된 것이 관찰되었으며, $\mathrm{Ca}$ 를 $1 \mathrm{wt} . \%$ 첨가하였을 때에는 조대한 봉상모양의 $\mathrm{CaMgSn}$ 가 생성된 것을 확인할 수 있다.

일반적으로 결정립 크기는 합금의 기계적 특성에 큰 영향을 미친다. 따라서 용체화 처리를 통해 시험편의 결정립 크기를 관 찰하였으며, 미세조직사진 및 결정립크기 측정결과를 Fig. 3에 나타내었다. Mg-Al-Sn-Ca합금의 $\mathrm{Ca}$ 첨가량이 증가함에 따라
결정립크기는 미세하게 관찰되었다. 또한 $\mathrm{Ca}$ 가 $0.7 \mathrm{wt} . \%$ 첨가 시에는 결정립 미세화 효과가 뚜렷이 나타났으며, $0.7 \mathrm{wt} . \%$ 이상 첨가 시에는 추가결정립 미세화 효과가 미미하게 나타났다. $\mathrm{Ca}$ 는 $\mathrm{Zr}$ 다음으로 효과적인 결정립 미세화제로 알려져 있으며 [12], $\mathrm{Ca}$ 첨가에 따른 조성적 과냉의 심화로 응고시 고액 성장 계면에 용질원자의 증가에 따라 결정립성장을 억제 할 뿐만 아 니라 조성적 과냉의 심화에 의한 결정핵의 확산에 의해 새로운 

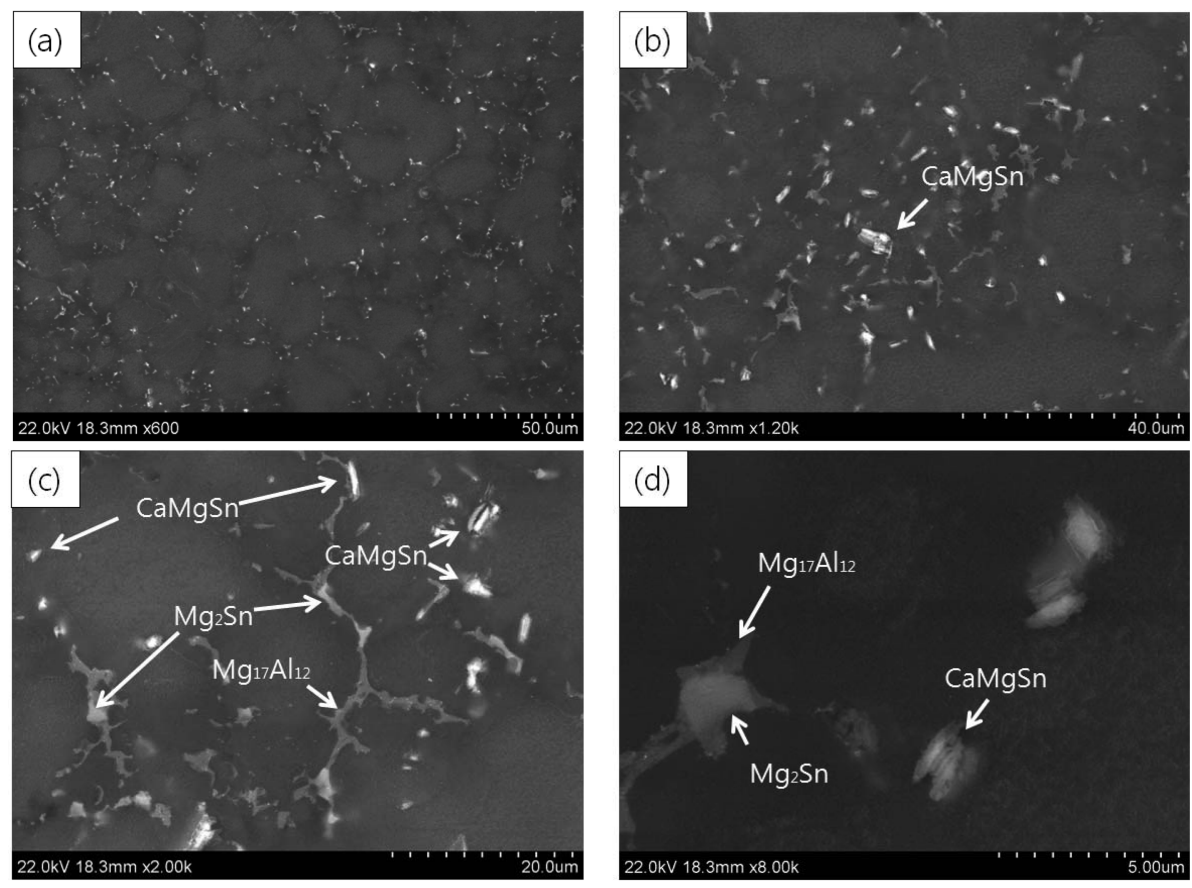

Fig. 6. SEM image of ATX420 $(\mathrm{Ca}=0.7 \mathrm{wt} . \%)$ alloy.
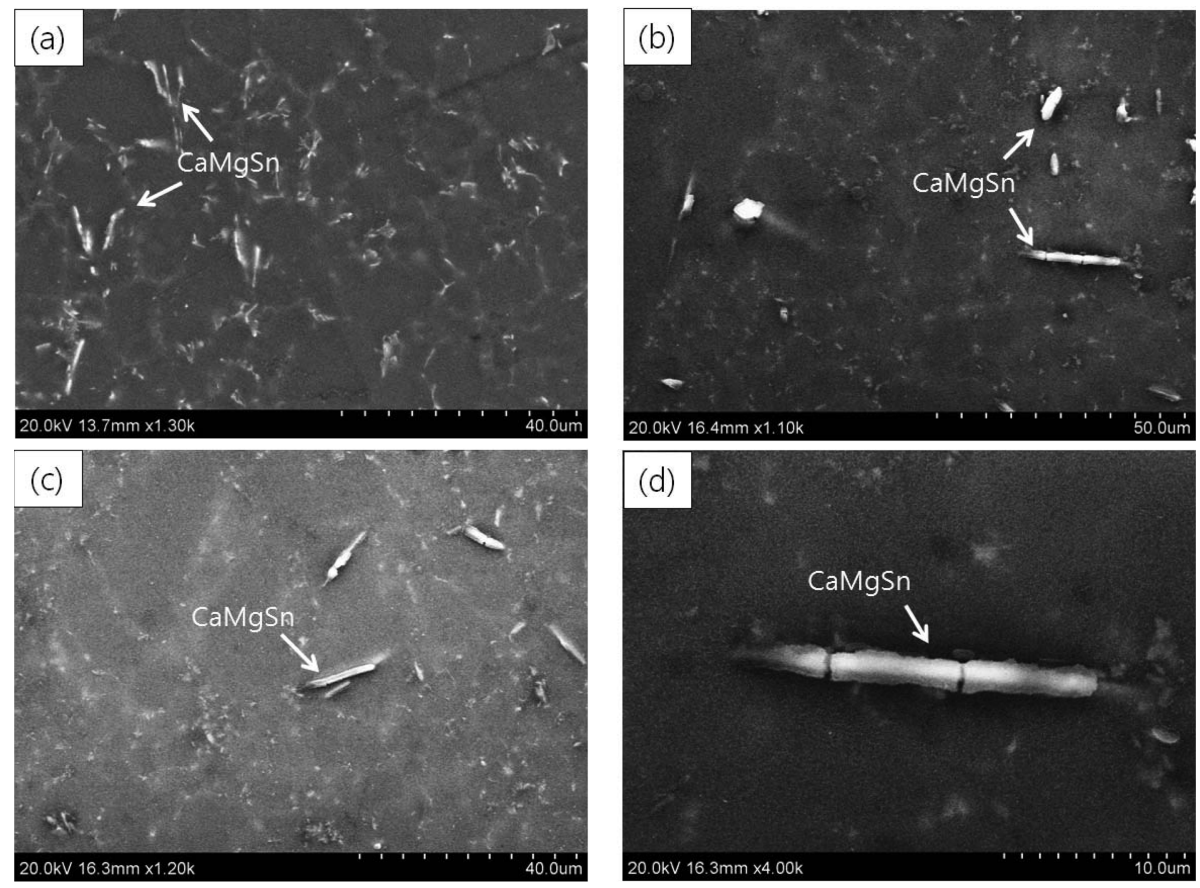

Fig. 7. SEM image of ATX421 alloy.

핵생성 사이트 역할을 하여 미세한 조직이 되었다고 사료된다 [13]. Kim[10]의 연구에 따르면 중력주조된 동일한 성분인 ATX421합금의 결정립 크기는 약 $105 \mu \mathrm{m}$ 로 보고 된 바 있으 며, 본 연구를 통하여 다이캐스팅으로 제작된 ATX421합금과 결정립 크기를 비교해 본 결과, 전체적인 결정립의 크기는 다이 캐스팅으로 제작된 시험편이 중력주조된 시험편 보다 약 $50 \%$ 정도 더 미세한 것으로 관찰되었다. 이는 고압의 다이캐스팅으
로 인하여 수지상정과 석출물의 크기 및 형태가 미세해졌다고 사료되며, 이는 다이캐스팅시 나타나는 수지상 가지의 부서짐 현상과 금형내 냉각수에 의한 열전달이 가속화 되어 미세 수지 상정을 형성시킨 결과라 사료된다[14].

Fig. 4 7은 Mg-Al-Sn-Ca 합금에 $\mathrm{Ca}$ 를 첨가하였을 때 나타 나는 미세조직의 변화를 주사식 전자현미경을(FE-SEM) 이용하 여 관찰한 결과이다. 각상들의 성분은 SEM-EDS를 통해 분석 

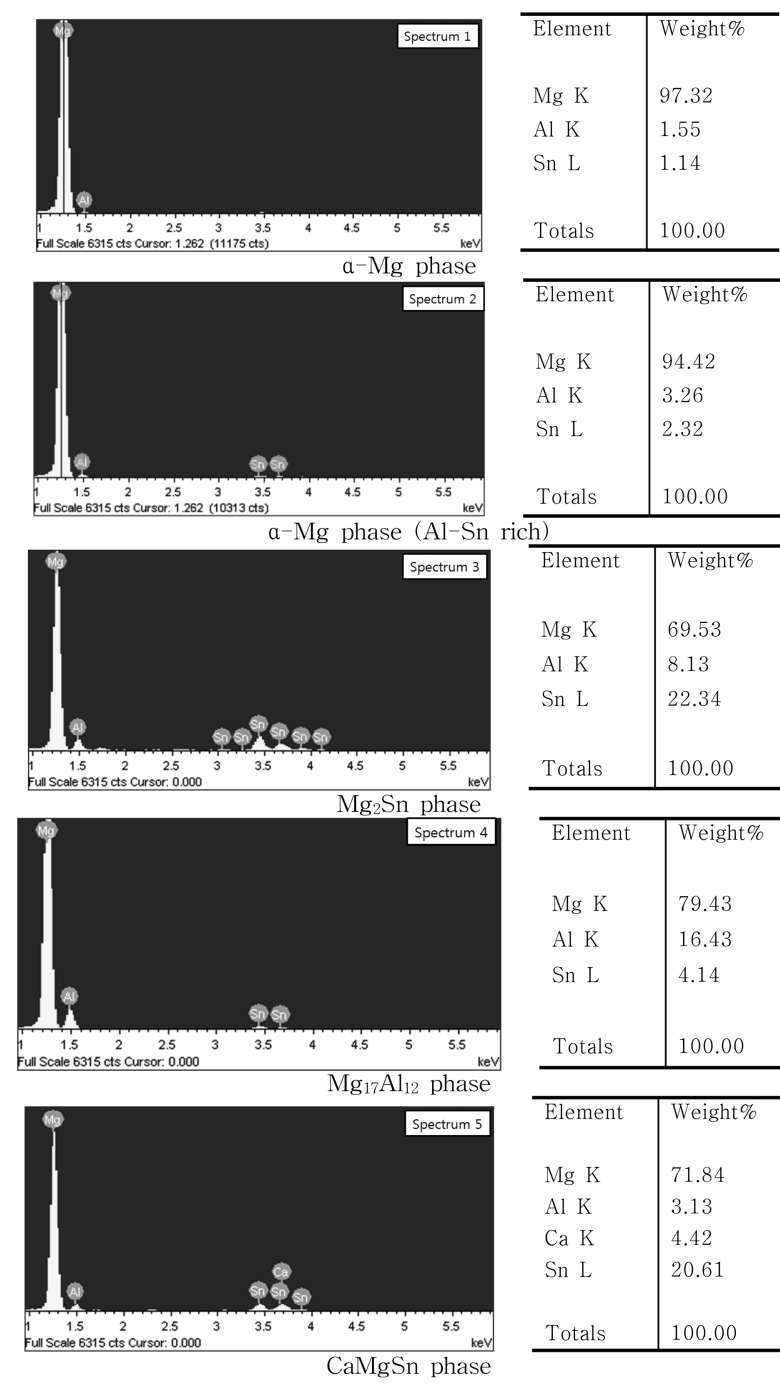

\begin{tabular}{|c|c|}
\hline h) & \\
\hline Element & Weight $\%$ \\
\hline $\mathrm{Mg} \mathrm{K}$ & 69.53 \\
\hline $\mathrm{Al} \mathrm{K}$ & 8.13 \\
\hline Sn L & 22.34 \\
\hline Totals & 100.00 \\
\hline Element & Weight\% \\
\hline $\operatorname{Mg~K}$ & 79.43 \\
\hline $\mathrm{Al} \mathrm{K}$ & 16.43 \\
\hline Sn L & 4.14 \\
\hline Totals & 100.00 \\
\hline Element & Weight\% \\
\hline Mg K & 71.84 \\
\hline $\mathrm{Al} \mathrm{K}$ & 3.13 \\
\hline $\mathrm{Ca} \mathrm{K}$ & 4.42 \\
\hline Sn L & 20.61 \\
\hline Totals & 100.00 \\
\hline
\end{tabular}

Fig. 8. SEM mapping micrographs of HPDC ATX420 $(\mathrm{Ca}=0.7$ wt.\%) alloy and EDS analysis of secondary phase.

하였으며 그 결과를 Fig. 8에 나타내었다.

Fig. 8의 EDS-Mapping 분석결과 $\alpha-\mathrm{Mg}$ 상의 중심에서 계면으 로 갈수록 $\alpha-\mathrm{Mg}$ 내 $\mathrm{Al}, \mathrm{Sn}, \mathrm{Ca}$ 의 함량이 증가하며, 계면에 생 성된 이차상을 따라 용질 원소가 분포되어 있음을 관찰할 수 있다. Fig. 4 에 나타난 ATX420 합금의 미세조직은 $\alpha-\mathrm{Mg}$ 상이 밝은 영역으로 보이며, 그 주위에는 $\mathrm{Al}$ 및 $\mathrm{Sn}$ 을 함유한 a$\mathrm{Mg}(\mathrm{Al}-\mathrm{Sn})$ rich상이 어둡게 보인다. $\mathrm{Mg}_{2} \mathrm{Sn}$ 및 $\mathrm{Mg}_{17} \mathrm{Al}_{12}$ 상은 입계사이 사이에 불연속적으로 석출되어있음을 관찰할 수 있다. Fig. 5에서 알 수 있듯이 $\mathrm{Mg}_{2} \mathrm{Sn}$ 은 polygon 형태로 있으며, Fig. 4(d)에서 알 수 있듯이 $\mathrm{Mg}_{2} \mathrm{Sn}$ 주위로 $\mathrm{Mg}_{17} \mathrm{Al}_{12}$ 상이 형성 되는 것이 관찰되었다. $\mathrm{SEM}$ 분석 결과 $\mathrm{Ca}$ 첨가량이 $0.3 \sim 0.7$ wt.\%일 때의 $\mathrm{CaMgSn}$ 상은 입계에 분산되어 있으며, 형태는 Fig. 6에서 알 수 있듯이 불규칙적이고 미세하게 관찰되었다. $\mathrm{Ca}$ 가 $1 \mathrm{wt} . \%$ 가 첨가된 ATX421 합금의 경우는 Fig. 7에서와 같이 봉상 형태의 조대한 $\mathrm{CaMgSn}$ 상이 입내 및 입계에 생성 된 것을 관찰할 수 있다. 조대한 $\mathrm{CaMgSn}$ 상이 입내와 입계에 서 관찰 되는 것은, 조대한 $\mathrm{CaMgSn}$ 상이 초정으로 생성되며
그 주위로 결정이 성장하였기 때문이라 사료된다.

\section{3 미세기포}

주조 시 발생하는 기포는 합금성분, 주조조건 및 금형디자인 등에 영향을 받으며, 미세기포생성 원인중 하나는 용탕의 불완전 한 feeding에 의한 응고수축에 있다. 응고가 진행되는 동안 수지 상정의 interlocking이 발생하여 용탕의 고립이 발생하고, 이 부 위에 부족한 용탕을 지속적으로 공급하여 주는 것을 feeding이라 한다, 이러한 feeding은 응고시 발생하는 고상율에 따라 liquid feeding, mass feeding, interdendric feeding, solid feeding으로 나누어지며 Fig. 9은 feeding mechanism을 그림으로 나타낸 것 이다. liquid feeding은 응고점 이상의 온도에서 용탕이 자유롭 게 흐르는 부분이며 불충분한 liquid feeding은 초기 기공형성을 유발시킨다. 핵생성이 시작되어 등방성의 수지상정이 자라기 시 작하는 부분을 mass feeding 이라 하며 mass feeding 구간은 반고상 상태에서 슬러리의 이동으로 feeding이 발생한다. liquid feeding 및 mass feeding은 용탕이 수지상정 사이에 자유롭게 공급이 가능한 구간이기 때문에 미세 기포발생에는 그다지 큰 영향을 미치지 않는다. 하지만 응고가 진행되면서 수지상의 고 상율이 증가하며, 각기 다른 수지상 가지들이 서로 만나게 되 는데 이때 고액 공존 구간에서의 고상비율은 $50 \%$ 이상이며, 수지상정의 interlocking에 의하여 용탕의 고립이 발생한다. 이 구간을 interdendric feeding이라 하며, 이때 용탕의 흐림은 급 속도로 저하되며, 주조성 및 interdendrite의 응력에 의해 결정 의 크기 및 형태가 달라진다. Interdendric feeding이 진행되는 동안 interlocking된 수지상의 응력이 낮은 부위는 수지상 가지 들이 서로 붕괴되면서 feeding이 진행이 되는데, 이때를 burst feeding이라 하며, 이 구간에서 거대한 용탕의 고립이 발생되기 도 한다. burst feeding시 interlocking 부위의 용탕 충진은 용 탕의 주조성에 따라 달라지며, 이는 미세기포 발생에 큰 영향 을 미친다. Burst feeding시 주조성이 높은 금속 일수록 응고 시 수지상정 interlocking 부위에 용탕을 충분히 공급할 수 있 어 미세기포를 감소시킬 수 있다. Solid feeding 구간은 응고가

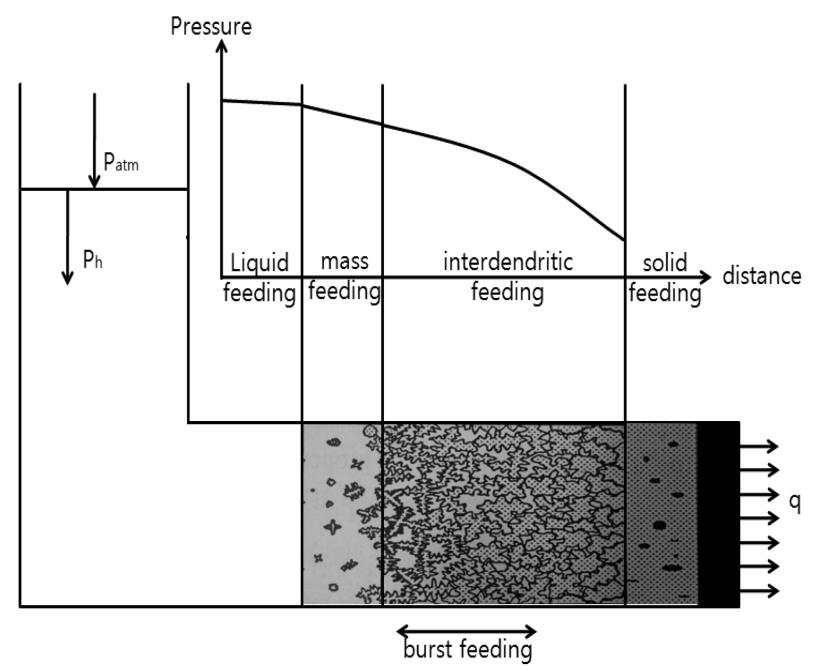

Fig. 9. Feeding mechanisms for a plate casting cooled from one end, solidifying with equiaxed dendrite[15]. 


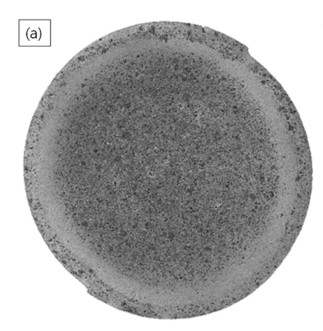

ATX420
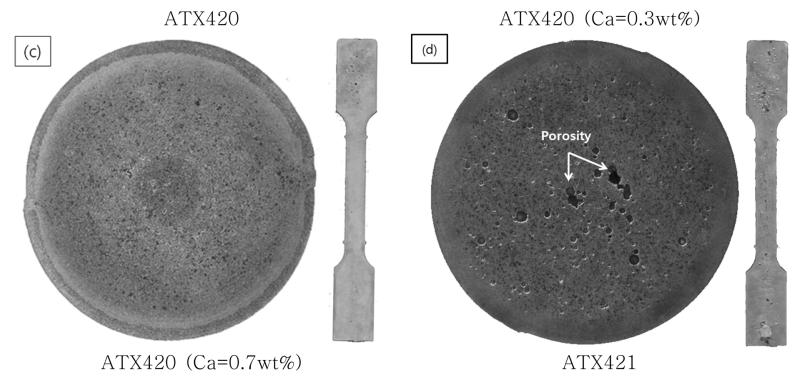

Fig. 10. Cross section of ATX420 alloys with different content of Ca additions: (a) 0wt.\% (b) $0.3 w t . \%$ (c) $0.7 w t . \%$ (d) $1 w t . \%$.

완료되는 구간으로 용탕이 충분히 공급되지 못한 부위는 미세기 공이 발생하여 기계적특성을 저하시킨다[15]. Dahle의 연구에 따르면 마그네슘합금 주조 시 첨가원소량의 증가에 따른 응고구 간의 확대는 응고 시 고액공존구간 영역을 넓히고, 이는 burst feeding 구간을 증가 시키는 역할을 하게 된다. Burst feeding 구간이 증가함에 따라, 고립된 용탕으로 feeding이 더욱 어려워 져 미세기포 발생량이 증가 한다는 보고가 있다[16].

Fig. 10은 Ca 첨가량에 따른 ATX420 합금의 단면사진을 나 타낸 그림으로 $\mathrm{Ca}$ 의 첨가량이 증가 할수록 내부의 미세기포 발 생이 점차적으로 증가하는 양상을 보이고 있다. 이는 $\mathrm{Ca}$ 의 첨가 량이 증가할수록 응고 시 응고구간 및 burst feeding구간이 길 어짐에 따라 원활한 feeding이 이루어지지 못했다고 사료된다. Fig. 10(d)에서 보듯이 $\mathrm{Ca}$ 가 $1 \mathrm{wt} . \%$ 첨가 시에는 조대한 미세기 포가 내부에 다량 발생하였으며, 이는 Ca가 $1 \mathrm{wt} . \%$ 첨가시 발생 하는 조대한 초정 $\mathrm{CaMgSn}$ 상에 의한 주조성 감소가 feeding을 방해하는 역할 및 용탕의 고립을 야기하기 때문에 미세기포의 발생을 더욱 증가시키는 것으로 사료된다.

\section{4 기계적특성}

$\mathrm{Ca}$ 첨가량에 따른 ATX 합금의 인장특성결과를 Fig. 11에 나 타내었다. Fig. 11(a)은 상온인장시험 결과로써 최대인장강도는 ATX421 $<$ ATX420 < ATX420 $(\mathrm{Ca}=0.3 \mathrm{wt} . \%)<\mathrm{ATX} 420(\mathrm{Ca}=$ $0.7 \mathrm{wt} . \%)$ 순으로 $\mathrm{Ca}$ 가 $0.7 \mathrm{wt} . \%$ 일때 최대인장강도를 나타내는 것으로 관찰되었다.

$\mathrm{Ca}$ 가 $0.7 \mathrm{wt} . \%$ 함유된 $\mathrm{ATX} 420$ 합금의 인장특성이 가장 높게 측정된 이유는 미세조직관찰에서 알 수 있듯이, $\mathrm{Ca}$ 에 의한 결 정립 미세화 효과 및 미세한 이차상들이 입계에 전반적으로 분 포 하고 있기 때문에 이로 인한 강화효과로 뛰어난 인장특성이 나타난 것이라 사료된다. ATX421 합금의 경우 ATX420에 비 하여 항복강도는 높으나 연신율이 급격하게 저하되는 것을 관찰 할 수 있는데, 그 이유로는 $\mathrm{Ca}$ 첨가에 따른 미세기공의 발생 및
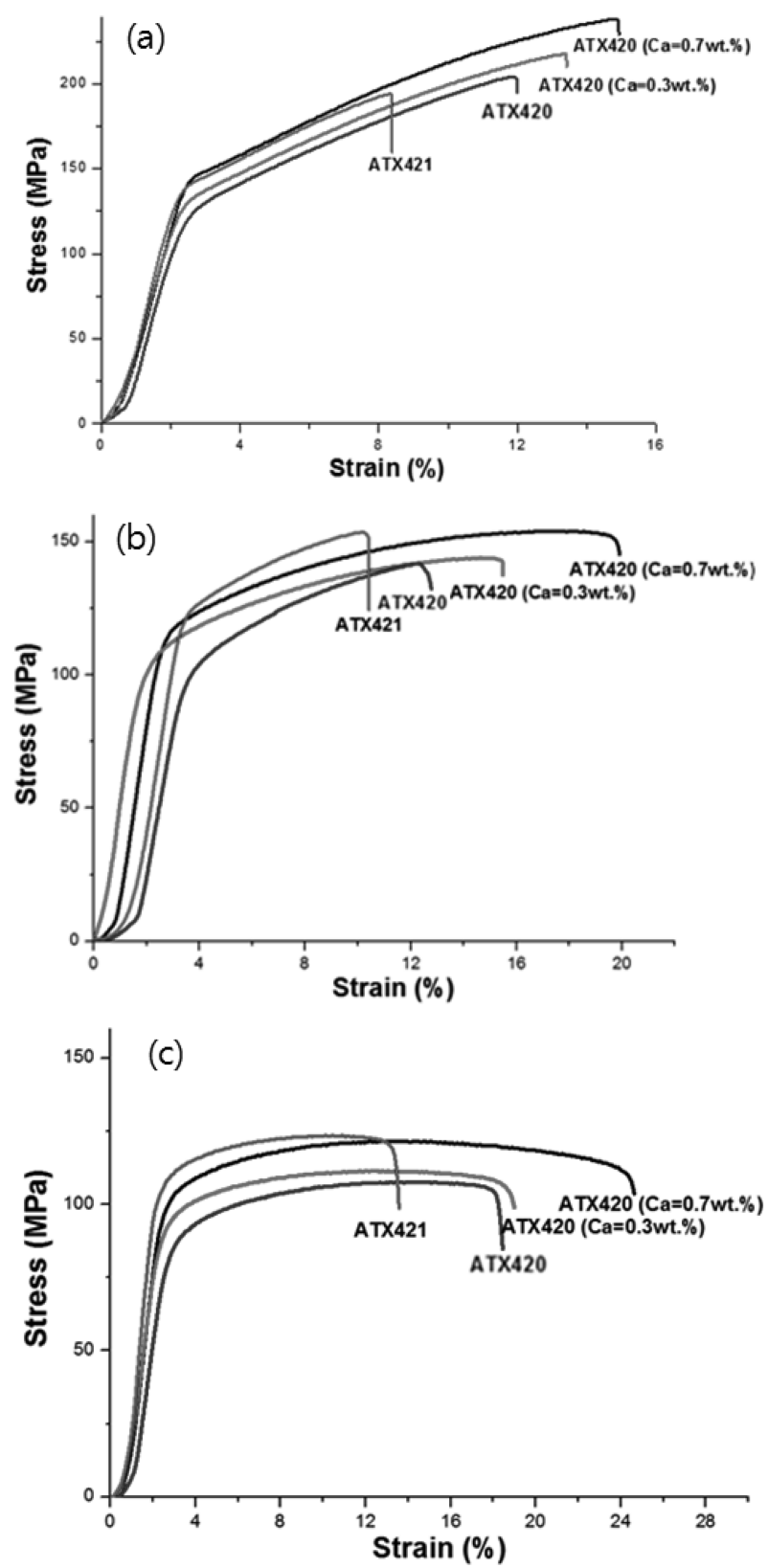

Fig. 11. Stress-strain curves of ATX420 alloys with different content of Ca additions.: (a) $25^{\circ} \mathrm{C}$, (b) $150^{\circ} \mathrm{C}$, (c) $200^{\circ} \mathrm{C}$.

증가 때문이며, 그 외에도 경하고 조대한 초정 $\mathrm{CaMgSn}$ 상의 생 성에 의하여 항복강도는 다소 상승하나 Fig. 12에서 나타나는 것과 같이 $\mathrm{CaMgSn}$ 상내의 균열 발생 및 $\mathrm{CaMgSn}, \alpha-\mathrm{Mg}$ 상의 계면사이에 발생하는 균열 때문에 연신율 및 인장강도가 오히려 $\mathrm{ATX} 420$ 보다 떨어지는 것으로 판단된다[17]. DSC를 이용하여 측정된 용융점 및 응고점을 통해 응고구간을 측정한 것을 Table 2에 나타내었으며, 이를 이용하여 Fig. 13에 Ca 함량에 따른 ATX420 합금의 응고구간 및 미세기포 생성에 관한 상관 관계를 나타낸 그래프를 나타내었다. Table 2에서 보여주는 바 와 같이 $\mathrm{ATX} 42$ 합금에 $\mathrm{Ca}$ 를 첨가할수록 응고구간이 증가되는 것이 관찰 되었으며, 응고구간이 증가할수록 미세기포의 발생량 또한 증가되는 것이 관찰되었다. 특히 $\mathrm{Ca}$ 가 $0.3 \sim 0.7 \mathrm{wt} . \%$ 첨가 


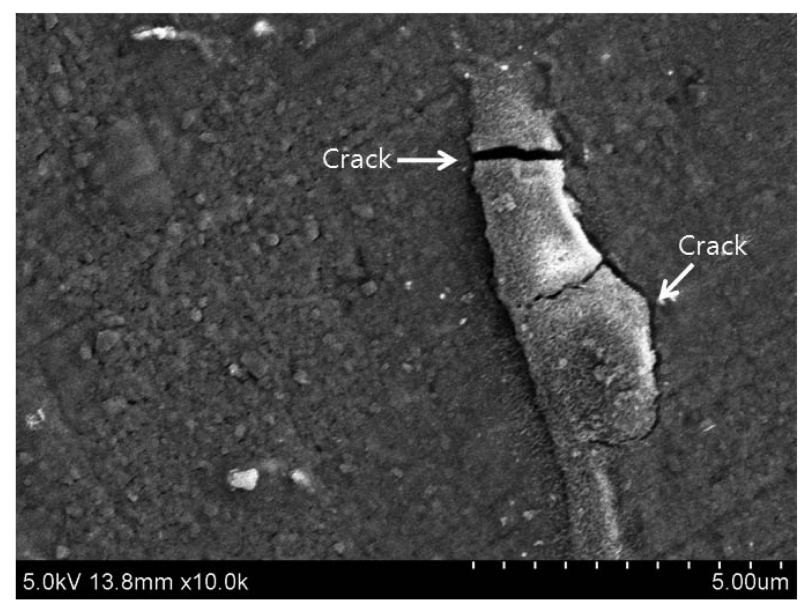

Fig. 12. SEM image of crack propagation at $\mathrm{CaMgSn}$ phase.

Table 2. Changes in the freezing range of ATX420 alloys with $\mathrm{Ca}$ additions.

\begin{tabular}{cccc}
\hline Alloy & $\begin{array}{c}\text { Liquidus } \\
\text { temperature }\left(\mathrm{C}^{\circ}\right)\end{array}$ & $\begin{array}{c}\text { solidus } \\
\text { templerature }\left(\mathrm{C}^{\circ}\right)\end{array}$ & $\begin{array}{c}\text { Freezing range } \\
\left(\mathrm{C}^{\circ}\right)\end{array}$ \\
\hline $\begin{array}{c}\text { ATX420 } \\
\text { ATX420 }\end{array}$ & 620.5 & 594.4 & 26.1 \\
$(\mathrm{Ca}=0.3 w t . \%)$ & 619.6 & 592.3 & 27.3 \\
$\begin{array}{c}\text { ATX420 } \\
(\mathrm{Ca}=0.7 w t . \%)\end{array}$ & 620.1 & 589.4 & 30.7 \\
ATX421 & 619.7 & 579.5 & 40.2 \\
\hline
\end{tabular}

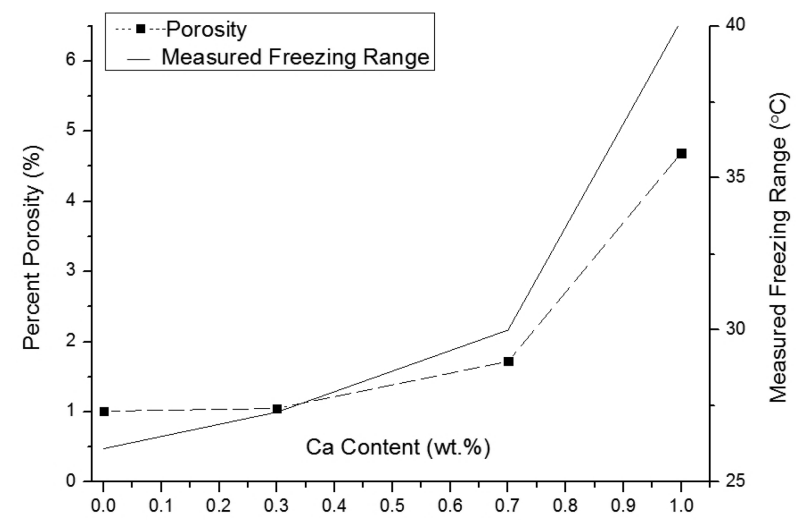

Fig. 13. Changes in the percentage porosity and freezing range with different content of $\mathrm{Ca}$ additions.

된 경우 미세기포의 양은 $1.01 \% ~ 1.72 \%$ 로 점차적으로 증가하나 $\mathrm{Ca}$ 를 $1 \mathrm{wt} . \%$ 첨가 시에는 $4.69 \%$ 로 미세기포가 급속도로 증가함 을 알 수가 있다. 이는 $\mathrm{Ca}$ 첨가량이 증가함에 따라 응고구간의 확대 및 조대한 초정 $\mathrm{CaMgSn}$ 상이 생성되어 burst feeding 구 간에서 용탕의 주조성을 급격히 저하시키는 것으로 사료되며, 이로 인해 원활한 feeding이 발생하지 못하고 수지상정 내 고 립된 부위에 용탕의 공급이 불완전하여 미세기포가 증가한 것 으로 사료된다[16]. $\mathrm{Ca}$ 첨가로 인한 미세기포 증가를 유발하는 요소로는 응고구간 증가로 인한 interdendritic feeding 방해 효
과 외에도 조성이 변화함에 따라 생성되는 초정상의 종류 또한 미세기포의 발생에 영향을 미치는 것으로 사료된다. Zhang[18] 의 연구에 따르면 $\mathrm{Ca}$ 의 첨가량이 $0.5 \mathrm{wt} . \%$ 이하일때 응고양상 은 액상으로 부터 $\alpha-\mathrm{Mg}$ 상이 초정으로 생성 되나 $\mathrm{Ca}$ 의 양이 $0.5 \mathrm{wt} . \%$ 이상인 경우 $\mathrm{CaMgSn}$ 상이 초정으로 먼저 생성된다고 보고된바있다. 따라서 $\mathrm{Ca}$ 가 $0.5 \mathrm{wt} . \%$ 이상 첨가시 조대한 $\mathrm{CaMgSn}$ 상이 초정으로 생성되어 수지상정 사이에서 용탕의 흐름 을 방해하는 역할로 작용하게 되며, 이는 수지상정 interlocking 시 조대한 공간을 형성 하여 고립된 용탕의 양을 증가시키고, burst feeding시 주조성을 저하시켜 미세기포의 발생을 증가시키 는 것으로 보인다[15,16]. $\mathrm{ATX} 420$ 합금에 $\mathrm{Ca}$ 가 $1 \mathrm{wt} . \%$ 첨가된 경우에는 초정으로 정출된 조대한 $\mathrm{CaMgSn}$ 상에 의해 미세기포 가 급격히 증가하는 것으로 판단되며, $\mathrm{Ca}$ 가 $0.7 \mathrm{wt} . \%$ 첨가된 경 우 미세조직 및 기포율 관찰을 해본 결과 초정 $\mathrm{CaMgSn}$ 상이 생성은 관찰되나, 미세한 초정 $\mathrm{CaMgSn}$ 상이 생성되어 주조성 및 미세기포 발생에 큰 영향을 미치지 않은 것으로 사료된다.

Fig. 11(b,c)에서 나타난 고온 인장시험결과 전체적인 $\mathrm{ATX}$ 합 금에서 온도증가에 의한 항복강도 및 인장강도의 저하가 나타났 으며, 상온인장시험과 마찬가지로 $1 \mathrm{wt} . \% \mathrm{Ca}$ 첨가시 미세기포에 의한 급격한 연신율 저하가 관찰되었다. ATX420합금이 가장 낮은 고온 인장강도를 나타났으며, $\mathrm{Ca}$ 의 첨가량이 증가 할수록 고온에의 기계적 특성이 향상되었다. ATX420합금 $(\mathrm{Ca}=0.7$ wt.\%)의 경우 연신율 및 강도 면에서 모두 우수한 성질을 나타 났으며, 상온 인장강도가 가장 낮았던 ATX421 합금은 고온에 서 가장 높은 인장강도을 나타내는 것으로 관찰되었다. 이는 열 적으로 불안정한 $\mathrm{Mg}_{17} \mathrm{Al}_{12}$ 상과는 달리 $800^{\circ} \mathrm{C}$ 이상의 온도에서 도 열적 안정성이 우수한 $\mathrm{CaMgSn}$ 상이 미세하게 분산 되어 있 어 결정립계 pinnnig효과에 의하여 전위의 이동 및 고온에서 취약한 $\mathrm{Mg}_{17} \mathrm{Al}_{12}$ 상의 결정립계 미끄러짐(grainboundary sliding) 현상을 억제한 것이라 판단된다. 또한 고루 분산된 이차상이 고 온 인장시 발생하는 균열의 전파을 막아주기 때문에 고온인장특 성이 향상되는 것이라 사료된다. ATX421합금의 경우 상온에서 균열의 원인이 되었던 조대한 $\mathrm{CaMgSn}$ 상이 고온에서는 오히려 균열의 전진을 억제하여 고온 인장강도 향상에 도움을 주는 것 으로 사료된다.

\section{4. 결 론}

다이캐스팅에 의해 제조된 Mg-Al계 합금인 Mg-4Al-2Sn 합 금에 고온인장특성에 미치는 $\mathrm{Ca}$ 의 영향을 평가하기 위하여 각 각 $0,0.3,0.7,1 \mathrm{wt} . \%$ 범위로 $\mathrm{Ca}$ 를 첨가하였으며, 미세조직관 찰 및 고온인장실험을 통하여 $\mathrm{Ca}$ 첨가에 따른 $\mathrm{ATX} 420$ 합금의 고온인장특성변화를 검토한 결과 다음과 같은 결과를 얻을 수 있었다.

1) 다이캐스팅을 통해 제작된 $\mathrm{Mg}-4 \mathrm{Al}-2 \mathrm{Sn}$ 합금은 $\mathrm{Ca}$ 함량 이 증가할수록 결정립크기는 미세해지며, $0.7 \mathrm{wt} . \% \mathrm{Ca}$ 이상 첨가 시에 발생하는 추가적인 결정립 미세화 효과는 미미하였다.

2) $\mathrm{Mg}-4 \mathrm{Al}-2 \mathrm{Sn}$ 합금에 $\mathrm{Ca}$ 첨가 시 나타나는 $\mathrm{CaMgSn}$ 상은 $0.7 \mathrm{wt} . \%$ 첨가 시까지는 불규칙한 형태로 대부분 입계에 미세하게 생성되었으며, $1 \mathrm{wt} . \% \mathrm{Ca}$ 첨가 시에는 조대한 봉상형태로 입계 및 
입내에 생성되는 것을 관찰할 수 있었다.

3) $\mathrm{Mg}-4 \mathrm{Al}-2 \mathrm{Sn}$ 합금의 상온 인장특성은 $\mathrm{Ca}$ 의 첨가에 따른 이차상 생성 및 결정립미세화 효과로 인장강도와 연신율이 항상 되는 것으로 사료되며, $\mathrm{Ca}$ 가 $0.7 \mathrm{wt} \%$ 일 때 가장 우수한 기계 적 특성을 얻을 수 있었다. 하지만 $\mathrm{Ca}$ 가 $1 w t . \%$ 일때는 인장강도 및 연신율이 오히려 떨어지는 결과를 얻을 수 있었다.

4) $\mathrm{Mg}-4 \mathrm{Al}-2 \mathrm{Sn}$ 합금의 고온 인장특성은 $\mathrm{Ca}$ 의 첨가량이 증가 될수록 항복강도 및 인장강도가 향상되었으며, 이는 고온에서 열적으로 안정한 $\mathrm{CaMgSn}$ 상이 결정립계 pinnnig 및 균열의 전 진을 방해하는 역할을 하였기 때문이라 사료된다. $\mathrm{Ca}$ 첨가량이 증가할수록 연신율은 점차적으로 증가되었으며, $1 \mathrm{wt} . \% \mathrm{Ca}$ 를 첨 가 시에는 미세기포 발생에 의한 급격한 연신율의 저하현상이 관찰되었다.

5) $\mathrm{Mg}-4 \mathrm{Al}-2 \mathrm{Sn}$ 합금에 $0 \sim 1 \mathrm{wt} . \% \mathrm{Ca}$ 를 첨가하였을 시 나타나 는 freezing range 및 미세기공율의 변화를 관찰한 결과 $\mathrm{Ca}$ 첨가 량이 증가할수록 freezing range 및 미세기포량은 증가하는 결 과를 얻을 수 있었다. $\mathrm{Ca}$ 첨가에 따른 freezing range의 증가는 응고 시 interdendritic feeding 구간을 증가시켜 feeding을 방해 하는 요소가 되며, 이는 미세기포 발생을 증가시키는 주된 원인 이 되는 것으로 판단된다. 또한 $\mathrm{Ca}$ 를 $1 \mathrm{wt} . \%$ 첨가시 발생하는 조대한 $\mathrm{CaMgSn}$ 상은 원활한 feeding을 방해하여 미세기포의 발 생량을 급격히 증가하는 것으로 판단된다.

6) 다이캐스팅을 적용한 $\mathrm{Mg}-4 \mathrm{Al}-2 \mathrm{Sn}$ 합금 제작 시 발생하는 미세기포의 분율은 $\mathrm{Ca}$ 첨가량이 증가할수록 높아지며, $1 \mathrm{wt} \% \mathrm{Ca}$ 를 첨가하였을 시에는 미세기공이 다량 발생하여 연신율이 급격 히 저하되는 결과를 얻을 수 있었다. 이는 $\mathrm{Ca}$ 의 첨가에 따른 응고구간 증가와 조대한 $\mathrm{CaMgSn}$ 초정이 interdendritic feeding 을 방해하는 역할을 하여 미세기포 발생이 심화된다고 판단된다. 또한 조대한 $\mathrm{CaMgSn}$ 상에 의한 crack initiation 역시 기계적 강도저하에 영향을 미치는 것으로 사료된다.

\section{참고문헌}

[1] M. M. Avedesian and hugh Baker: "Magnesium and Magnesium alloys" ASM Specialty Handbook, (1999) 3-7

[2] Alan A. Luo: JOM, "Magnesium-Current and Potential Automotive Applications" 54(2) (2002) 42-48

[3] Alan A. Luo; Int. Mater. Rev. 49 (2004) 13-30
[4] Naomi Nishi: J. Kor. Foundrymen's Soc, "History of Magnesium Die Casting" 29(1) (2009) 20-26

[5] Frank Czerwinski: "Magnesium Alloys-Design, Processing and Properties" InTech, (2011) 265-266

[6] Ming-bo YANG, Liang CHENG and Fu-sheng PAN: Transactions of Nonferrous Metals Society of China, "Comparison of as-cast microstructure, tensile and creep properties for $\mathrm{Mg}-3 \mathrm{Sn}-1 \mathrm{Ca}$ and Mg-3Sn-2Ca magnesium alloys", 20 (2010) 584-589

[7] Mingbo Yang, Fusheng Pan, Liang Cheng and Jia Shen:: Mater. Sci. Eng.(A), "Effects of cerium on as-cast microstructure and mechanical properties of Mg-3Sn-2Ca magnesium alloy" 512 (2009) 132-138

[8] Alan A. Luo: "Cast magnesium alloys for elevated temperature applications" 29(20)(1994) 5259-5271

[9] S. H. Ha, J. K. Lee, S. K. Kim: J. Kor. Foundrymen's Soc, "Development trend of high temperature Mg alloys" 27(5) (2007) 193-197

[10] B. H. Kim, K. C. Park, Y. H. Park and I. M. Park: Mater. Sci. Eng.(A), "Investigations of the properties of Mg-4Al-2Sn-1CaxCe alloys" 527 (2010) 6372-6377

[11] B. H. Kim, K. C. Park, Y. H. Park and I. M. Park: Mater. Sci. Eng.(A), "Effect of $\mathrm{Ca}$ and $\mathrm{Sr}$ additions on high temperature and corrosion properties of Mg-4Al-2Sn based alloys" 528 (2011) 808-814

[12] Y. C. Lee, A. K. Dahile, D. H. Stjohn : Metall. Mater. Trans. A, Vol. 31A, November (2000) 2895

[13] N. E. Kang : Pusan Univ, "Effect of Ca addition in the Mechanical Property and Deformation Behavior of AZ31 Magnesium Alloy Extrusions" 2010

[14] B. Andresen: "Die Casting Engineering", Marcel Dekker, New York, NY, (2005) 209-236

[15] A. K. Dahle, D. H. Stjohn :UNESCO Encyclopedia of Life Support Systems, in press, "Processing from the liquid state"

[16] A. K. Dahle, Y. C. Lee, M. D. Nave, P. L. Schaffer, D. H. Stjohn : Journal of Light Metals, "Development of the As-Cast Microstructure in Magnesium-Aluminium Alloys", 1(1), (2001) 61-72

[17] B. H. Kim, K. C. Park, Y. H. Park and I. M. Park: Transactions of Nonferrous Metals Society of China, "Microstructure and creep properties of $\mathrm{Mg}-4 \mathrm{Al}-2 \mathrm{Sn}-1(\mathrm{Ca}, \mathrm{Sr})$ alloys", 20 (2010) 1184-1191

[18] C. Zhang, H. Cao, V. Firouzdor a, S. Kou a, Y. A. Chang : Intermetallics, "Microstructure investigations of directionally solidified Mg-rich alloys containing Al, Ca and Sn” 18 (2010) 1597-1602 